\title{
Kalighat Paintings: A National Artifact, the Folk and Counter Representation in the Making of Modern Art in Bengal
}

\author{
Anuja Mukherjee \\ M.A in Anthropology student, Columbia University New York City. \\ Email:anuja.m@columbia.edu
}

\begin{abstract}
Kalighat Patachitra is a style of paintings that came into being in nineteenth century Calcutta after which its active practice died out by the beginning of the next century. My detailed focus in this article will be Kalighat Paintings and its emplotment in the question of national identity, with the loss of ritual importance, defamation and eventual museumization.
\end{abstract}

Keywords: Kalighat Patachitra, fragmentation, nationalism, folk art.

\section{Introduction}

Khalighat paintings are significant cultural artifacts from an era where folk came face to face with the urban elite. It was a clash of identities that resulted in Kalighat paintings. However, this clash was only one of many results that were a part of the creation of popular culture in Bengal in the nineteenth century. In the first segment I have explored a part of the journey that these paintings made through Kalighat to various museums around the world.

In the first segment I have covered the migration of the artists, its effects, ritual importance of these paintings, formation of sub genres in a genre and its genesis. I have explored the importance of the market area around the Kalighat temple and the intricate group effort of making these paintings as opposed to the urban sole artist behind a painting (Dey, 1933). The reactionary nature of these paintings is what mainly engulfs this segment, where even this nature is perceived differently by various art historians. The shift from painting from one's imagination to painting what we observe has been touched upon with the example of this western influence and the artistic subversion that caused the painters to draw Babu's and Bibi's along with God's, Goddesses and Beasts (Pinney,2004). The possibility of looking at the 'Babu' figure as the embodiment of beastly characteristics and 'Bibi' sharing traits with, Kali the deviant yet powerful beastlike goddess has been thoroughly discussed.

In the upcoming segments the Kalighat market as a place of coexistence with other artists, the biased reproduction of these paintings will be discussed. I mainly plan to work on the fragmentation of experiences that led to the formation of Kalighat patachitra and the role of humor in pacifying a seemingly non-violent image creation. The transition of folk culture to popular culture and Kalighat paintings as a form of protest against a different idea of nationalism in Bengal in the 19th century along with the role of migration in the life of artists especially artists who travel with families in groups due to the their collective process of creating art and depersonalizing it as opposed to the idea of a sole creator of art. The paintings will act as the primary text for this part of my research. All of this with a parallel commentary of the emerging

(C) AesthetixMS 2020. This Open Access article is published under a Creative Commons Attribution Non-Commercial 4.0 International License (http://creativecommons.org/licenses/by-nc/4.0/), which permits non-commercial re-use, distribution, and reproduction in any medium, provided the original work is properly cited. For citation use the DOI. For commercial re-use, please contact editor@chitrolekha.com 
Bengal school of art and its pioneers like Mukul Dey and Abanindranath Tagore in the nineteenth century.

We can, therefore, look at Kalighat paintings to have pointed out two moments of nationalism in two classes and in two styles of folk art. The first one being a continuous process of protecting one's national identity through ridicule and satirization of a hybrid form of their imagined national Bengali upper class as opposed to a dialogue with the British through adapting to a way of life similar to theirs in the process of seeking a new national identity as a person of the upper class. These were the two imaginations of the nation that was at play. The second moment of nationalism was divided between Jamini Roy and Kalighat painters, where Jamini Roy's inspired perspective of the practice of folk art in the urban set up was in opposition with Kalighat paintings that were anonymous and mostly didn't have a single creator. The power of the single elite creator of 'folk' art against that of the influence of a group of artists who were constantly trying to evolve their way of making away from direct folk influence, only to define and become a new form of art. All four insights give us an idea of how the vernacular seemed to be in distress and its protection in various ways created a conflict of nationalistic ideas in different classes.

The chronology of the segments is based on the movement of the paintings from the village to the city followed by changing of form into lithographs and finally the displacement into the world of museums, while summing it up using the current state of practice of this style of art and its significance.

\section{The Movement of Kalighat Paintings}

The beginning of Kalighat patachitra as a practiced style of art was around 1830, when the pat artists who resided in the outskirts and nearby villages of Calcutta, migrated to Calcutta. I specifically identify the genesis of this style of art with the physical movement of the artists to Kalighat due to a sharp shift in style. This move was economically influenced by the formation of a market area around the Kalighat temple. This market offered a different sense of employment to these artists who changed the entire basis of patachitra, from where they once began. Now, what we must understand is that this leap wasn't a short one. These artists had to change the very structure that had made their art buyable and had attached entertainment value to it along with obvious traditional/ cultural importance. They did away with the storytelling and the 'performance' aspect of the paintings, made the current paintings smaller in size as a result of storytelling through one scene is known as 'chouko pot' instead of many. However, the performance was only subverted into a different form.

The market area that was home to many Kalighat paintings was mainly built for temple goers and tourists who took back souvenirs of their visit from this market. The catch behind these paintings was time-related. A customer would 'order' a painting before going to the temple and the painting would be done by the time this person was back. It was this uncanny 'art on request' feature of Kalighat paintings that continued as a reminder of the patachitras in Kalighat paintings. Calcutta as a space changed an entirely village based art form into an urban scheme of creating sociocultural artifacts for ages to come. A souvenir being essentially something one has seen or experienced at a place, the artists began with painting their rendition of the Kalighat Kali idol. "In the nineteenth century some British colonialists saw new representational techniques as a means of dismantling the Hindu world-view. Perceiving the great mass of Indians as inhabiting 'an era before art' and to be interested in images only as 'idols'. Colonial art educators sought to transform the intimate and interested engagement of the devotee into the disinterested and 
rationalized response of colonial political subjects to the image as 'art'. The history that follows is in part, set against colonial attempts to turn devotional images into 'art' "(Pinney, 2004)

Now, this is the reason why migration plays such an immense role in this discourse. The migration of this group of artists bought them a field of buyers that would buy their art rather than the village or local exhibitions that were already washed out with patachitra. In the nineteenth century, the temple was flooded by a certain class of people, essentially a class lower than that of the educated elites'. The process of buying this painting, which wasn't necessarily being performed in front of them but while they are away or purchasing a painting of the goddess right from a shop somehow demystified the notion of ritual from these paintings. They became more of keepsake, than a form of the idol that they worship. Kalighat paintings had successfully inclined the masses that were buying these paintings into buying 'art' which didn't entirely do away with the ritual importance of the painting but withered a considerable amount of it with the purchase. The visible effort of the artist made it more of a collectors treasure than an object of devotion. To become an object of devotion, these paintings had to transform into cheaper quality but richer color on glossy paper in the form of oleographs/lithographs. This is how these paintings were scattered across a century and quickly died out in practice. The "cult value" of these paintings decreased with a rise in their political importance which led to the immediate increase in 'exhibition value' (Benjamin, 2008).

Quickest accessible knowledge about Kalighat paintings speak very little but imply volumes

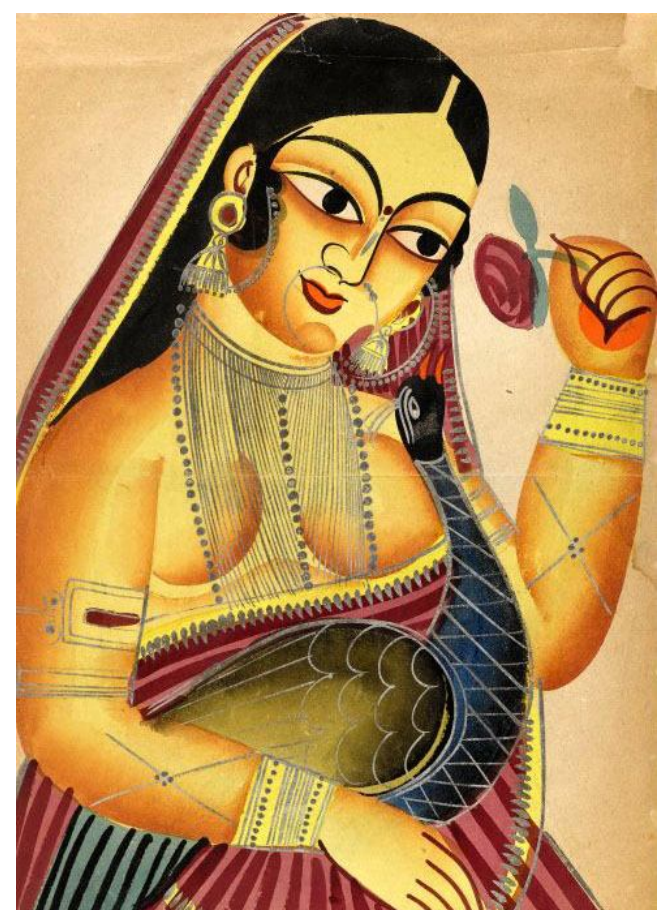

Figure 1 Goddess Lakshmi with a peacock and a rose. Artist unknown, Kalighat Patachitra, Brooklyn Museum. through this. The focus of this level of information continues to remain its formation but most importantly its extinction due to oleographs. This is a very simplistic generalized notion that is easy to imbibe. However, my study is about interrogating every simplistic stand taken regarding these paintings regarding its loss of practice. The transition from handmade paintings to cheap oleographs only sounds like an organic change due to technological advancement in Calcutta. The violence of this advancement was inflicted on this particular style of art due to a plethora of reasons. "Any attempt at an analysis of the cultural history of the nineteenth century Calcutta, therefore, must reject a unilinear interpretation and take into account the complexities and contradictions that prevailed in the cultural attitudes and manifestations of both the Elite and lower orders" (Banerjee, 1989).

Kalighat paintings, in my opinion, stand as a signifier of the moment in Indian nationalism through visual culture in the nineteenth century where the Orient met the Occident. I have carefully used the words Orient and Occident instead of 'the west' and 'east' because the discourse of Orientalism(Said, 1978) is far more telling as it speaks of defining and redefining. The Occident was exactly what the patuas were painting in the form of babu and not a just Bengali western educated male. So the patuas were defining the defined on paper. While we cannot ignore that the defined also performed its definition as a 'babu' but the patuas description of the babu was crass. In fact, it was too real to be real. 
It is evident that the idea that has formed around Kalighat patachitras is that it was reactionary. Before moving into this realm of thought, it is important to note that the most 'popular' and mass-produced oleographs (Pinney, 2004) were that of the paintings of gods and goddesses followed by important moments in history. The Babu, Bibi and their set of pets didn't quite make the cut for the long haul when it came to reproduction. The artists I strongly believe was extremely aware of their circumstances and the nature of what they were producing. While the Babu and Bibi wasn't just a set of paintings signifying the misgivings of the Bengali Elite, it was all the more reason to avoid having it around through cheaper sources. The market is still bursting with cheaply produced images of deities bought even to this day. Not surprisingly, The Babu and Bibi were left behind with only traces of memory. "Yet all this is true, although it has well-nigh become a thing of the past. Even to this day, if you will look with some penetration into a Calcutta pan and cigarette shop-a mere shanty at a street corner-you may find a litho picture in colour of a girl combing her hair, or a girl playing on the sitar, or Radha and Krishna, the divine lovers of Hindu mythology, underneath the Kadamba tree, or Rama and Sita, or Siva and Parvati, or so such other pictures of Hindu deities. These lithos are mostly imitations of Kalighat pictures, which invariably were hand-drawn and hand painted." (Pinney, 2004)Here and there a few prints of a seemingly non-scandalous Bibi is found combing her hair but nothing as real as Babu being hit by his mistress and his wife or two wives for that matter.

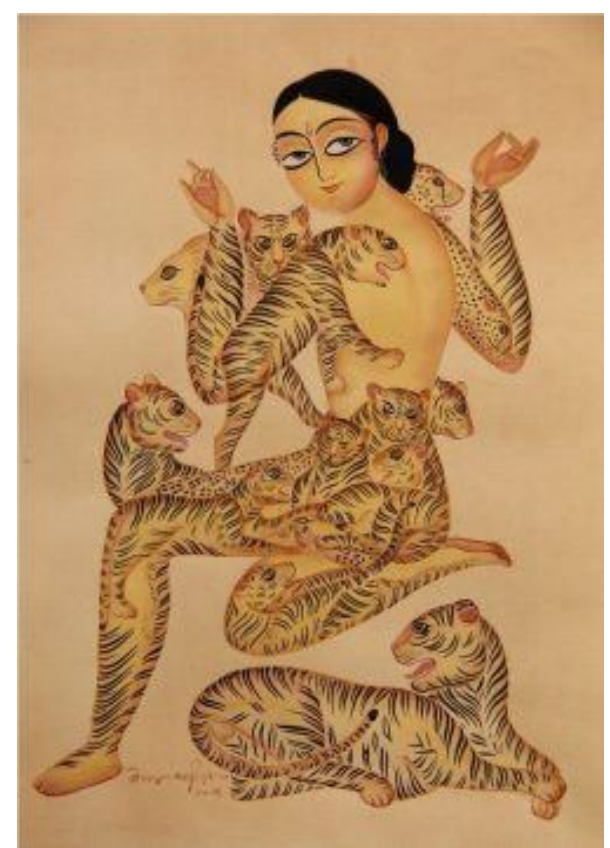

Figure 2 Tiger Woman. Artist Kalam Patua, Kalighat Patachitra.

Returning to the reactionary nature of these paintings in having painted the Elite, it is important to understand a simple concept regarding art. If art is imagined and what we imagine is nothing but what we experience everyday then art is bound to be mimetic (Plato) The deeper complexities of mimesis in Kalighat paintings with regard to imagination, is also what I want to explore in the next few segments. However, the shift from drawing beasts to humans that walk around us was definitely about a strong western influence but there is a relatively unexplored arena when it comes to looking at the major shifts in Indian art and in this case Kalighat Paintings that could be very much about an active tendency towards subversion. If the image of the Hindu goddess Kali was the beginning of Kalighat paintings and also the most popular one, it can also be described as an image of a woman who is imagined, unreal and beastlike. If Indians were used to painting beasts with more than two hands and two eyes, when the Babu and Bibi came in it was simple to think that the big shift from unreal to real was made. Yet, it misses the argument that comes from the origin of these paintings. "Calcutta's folk artistes who came from lower orders had a better understanding of the human situation than the more sophisticated elite. They had learnt the hard way to see through the illusion of property, wealth, power and ambition. Their songs and dramatic performances, their paintings and pantomimes therefore hit more directly against the habits of both the nouveaux riches and the orthodox Hindus - the Anglicized customs of the parvenu and the hypocrisy of the priests. Thus, in one sense, their cultural expressions could be interpreted as far more radical manifestation of social protest coming from the bottom, directed against both the new colonial influence and the old feudal customs, in a language that was more earthy and authentic than that cultivated by the educated 
gentry." (Banerjee, 1989) They were made by people belonging to the lower class with a complex identity issue due to conflicting religious identities (That of a Hindu and/or of a Muslim) that was mostly interchangeable as per convenience. On stepping into an unknown city which thrived on trade, everything was a real form of their imagination. Most importantly, the Indian Bengali Babu that was closer to home yet extremely unknown. If Indian artists were known for drawing beasts and deities in a pre- British era then maybe the patua was simply subverting his expression by continuing to draw his beast/ deity in the form of Babu and Bibi. Bibi, sometimes being the wife or a prostitute who was aggressively sexual, dominating and most importantly deviant matches the profile of the image of a deity who facilitated the formation of the Kalighat style of paintings. The violence in thinking simplistically about the role of the influencers and their pride in it, affects the way the masses perceived the paintings back then and how we perceive them today. This is also known as the 'culture of silence' (Banerjee, Friere, 1989) rightly noted by Paulo Freire where the voice of the colonized seems entirely relational and dependent. It sounds and in this case, looks like an echo of the colonizers. The process of silencing had three prongs. The first prong was the unbearable and slightly exaggerated mirror that was held in the faces of the elite, which is why they weren't exactly self-critical customers because the change into taking up government jobs and leading a different lifestyle was still relatively new and something as unsettling as a lower class ridiculing them through art meant this form of art should be done away with. This doing away wasn't a very visible or conscious effort in the face of some amount of guilt that also lingered in being a babu, in being privileged. The second prong was protection this identity through difference making. Folk culture was further folkised, it was essentialized and 'protected' in the birthplace of folk, which would keep this culture, away and at the same time create a crucial difference. Kalighat paintings had become the perfect example of folk gone wrong which is why folk should've remained in the village. Once folk travelled from the village and came face to face with the Elite, there were clear boundaries that were crossed and differences that needed to be made anew.

The third and final prong was museumization. If the value of art is measured in two social capacities, the first being transfer of ownership to a buyer for his/her own interests and the second being transfer of ownership to museums (either directly or through constantly changing ownership) then we can say that Kalighat paintings were fairly quickly museumised partly because the subverted folk was too real to keep at home and too subverted to send back to the village so the only way to lead it out of the current scenario was to quickly make it achieve the epitome of success around the time of its near extinction in practice. This transfer of ownership and the politics of it will be elaborated on in the next few segments.

\section{Interplay of the Visual Identities of Babu,Bibi and Baishya}

Nineteenth Century in Bengal was a period when women's education had taken up working space in the daily lives of those who were willing to empower Elite women into an arena of education that would possibly usher the mahila into becoming the bhadramahila (Bannerji, 1994, Bagchi, 1993). In the quest for women's education the prescribed nature and being of a woman was questioned by these paintings as they portrayed heterogeneous woman. Cohesive identity formation for both genders had become essential in order to counter the representation of the colonizer in the homeland (Ghosh, 1986, Sarkar, 1987).The nature of identity formation begun here, where the identity of self was created through the identity of the other that was merely a small reflection of the whole of the others. This also made it easy to otherize the other. In believing that the other had a homogeneous identity, it had become easier to tackle it by creating 
a homogenous identity of self. At the same time it had become important to focus on not just the public self but also the private. The private, moral self as protected by the female was about to be brought into the public to mimic and better the women of the other while tackling the issue of the other woman (Singh, 2007). The other woman was a product of the proliferation of flesh trade in nineteenth century Calcutta. This is where the baishya met the babu and the bibi.

In keeping with the need to form an identity for the moral, educated Bengali woman who would

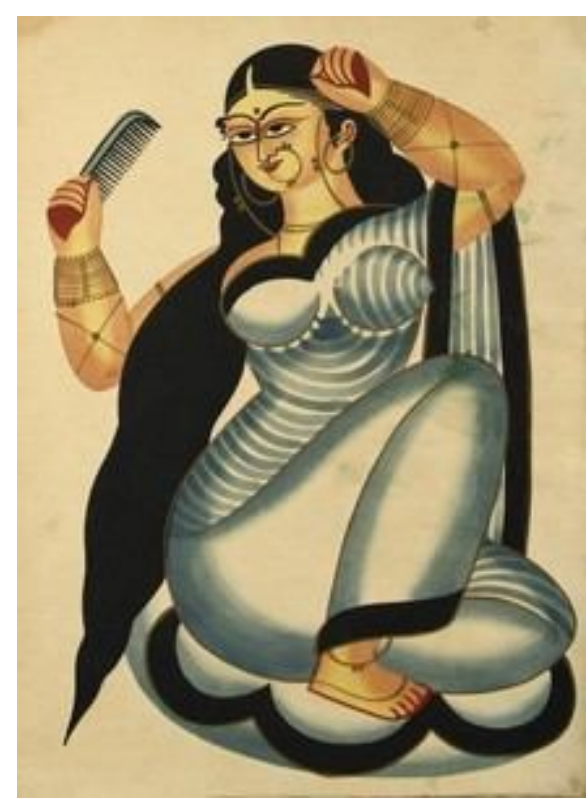

Figure 3 Lady combing hair. Artist Unknown, Kalighat Patachitra. uphold the private, these paintings had become a sizeable hindrance to this project of nationalism. The patuas openly portrayed the meeting of the two private lives of the bhadralok which ultimately bared not just the indulgences of the bhadralok but also the many sides of the potential one dimensional Bengali woman, her sexuality, her deplorable habits, her jealousy, and her control of the effeminate bhadralok was observed and brought out by the patua who was innovating his style of art by practicing his language of nationalism on paper and creating a product that would inflict tremors on elitist nationalism."In the entire phase of national struggle, the crucial need was to protect, preserve and strengthen the inner core of the national culture, its spiritual essence" (Chatterjee, 2000) The spiritual essence that Partha Chatterjee speaks of is a domain that these paintings revolutionized by handing the reality of prevalent masculine symbols like that of a hookah pipe, English shoes, instances of domestic violence and Overt sexuality, none of which adhered to the sanctuary that the private domain was homogenized to be.

The reason behind why Kalighat paintings faced negative sensationalism during its course of production was the fact that even the "new woman" who was supposedly educated to fit the social shapes, didn't live up to the image of herself in these paintings.

The patua intentionally created marked differences in the being of the Bengali woman, where one could tell if she was The Prostitute or the wife.

In the series of babu and bibi paintings it is evident that the bibi was just another category that had many branches of women who had different allocations in the society. Nonetheless they continued to be associated with the $B a b u$ who was portrayed as the colonized constant sartorially.

Numerically Babu fell short in comparison with the number of ways bibi was portrayed by the patua and none of them worked in favor of a singular identity of the bhadra. "The very recognition of this difference and divergence that empowers these representations and makes the female figure an ideal

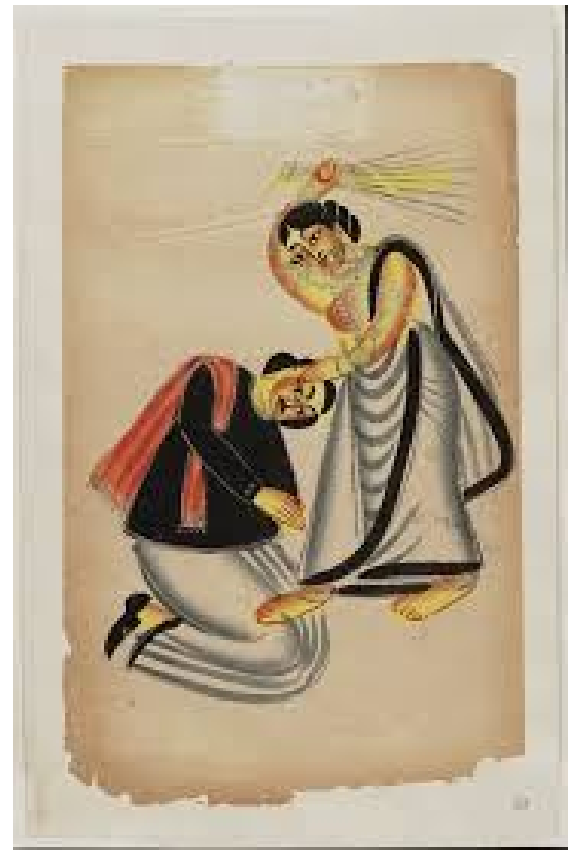

Figure 4 Woman striking man with broom. Artist unknown, Kalighat Patachitra. 
vehicle for allegory: for conveying meanings far beyond its immediate presence" (Guha Thakurata, 1991) Rather, the mahila was mostly looked at as the abhadra regardless of her social class through their portrayal in these paintings and thus much closer to the patua. The patua wasn't living up to his necessary image either of empowering women by deifying them through covert victimhood. He was actually engaging himself in his portrayal of the woman as one of his own, as obscene, varied and experimental.

The horizontal gap of knowledge systems of the folk from the metropolitan only magnified with time. However, the migrant folk artist shared the skepticism of western education with the women of that time. The folk were simply painting the metropolitan woman being subjected to both growth and preservation of knowledge systems that were ideal for women, while similar expectations were posed at the patua, to not let his spatial settings enter the sanctity of his creations even though his location had changed.

The Kalighat paintings remain a visual trajectory of these artists who portrayed the changes in their self through painting the other and in that he kept intact his folk tendencies."An important aspect of the folk culture of the lower orders of 19th century Bengal was ribaldry. The satisfaction of the body, from food to sex, was responsible for some of the wisest and wittiest proverbs and sayings, as well as some of the most rollicking and ribald songs and poems in Bengali folk literature of this period. An almost impenitent tendency to show up human follies and frailties by depicting humorously the normal and gross activities of ordinary mortals, to laugh at sex and with sex, which we find in these forms of cultural expressions reflected playfully a primitive sensuality" (Banerjee,1987).

The threat of intermingling identities was deeply felt due to its fresh roots in the bhadralok society, sharp lines cut through social workings of do's and don'ts as the elite had to co-habit with both, the patua and the English. A constant reminder from their 'obscene' roots was a calling that the Kalighat paintings and their popularity facilitated. Partha Chatterjee suggests, "much of the past literature on subaltern studies has concentrated almost exclusively on more openly rebellious and radical forms of resistance, often to the neglect of the more subtle, yet perhaps far more

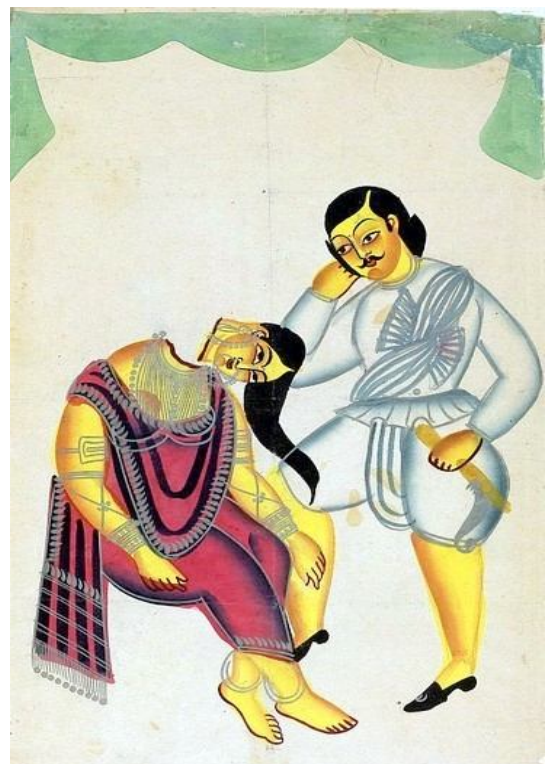

Figure $\mathbf{5}$ Tarakeshwar Affair, After the blow. Artist Unknown, Kalighat Patachitra. pervasive, forms of nonviolent, passive, and "everyday" forms of resistance (the "weapons of the weak").We must, after all, remind ourselves that subaltern consciousness is not merely structure, characterized solely by negativity; it is also history, shaped through a changing process of interaction between the dominant and the subordinate". ${ }^{2}$ (Chatterjee, 20oo) When we think of how an art form died out, it is essential to realize that the fluidity of an entire art form practiced by at least a few hundred must have struck a chord that had to be silenced eventually but entirely.

Through their everyday ways of doing folk and doing city, these paintings were retaining a quality of folk that is so usual that it's almost always considered to be a constant. Folk implies a lot of repetition and in that repetition it creates dominant symbols that when acted and reenacted become a reality on paper that transcends the artist's creation in itself. Like that of a fish, a spiral human chain or Goddess Laxmi's feet. 'This is not lack of innovation, nor is it imitation as understood in the metropolitans' copyright conscious market; 
this is a purposeful repetition of motifs in a traditional vernacular'( Das, 2010) .Even in the city, the patuas practiced repetition of symbols and these symbols were directly attached to the very being of a social class. The babu and bibi had become recurring symbols in changing scenarios of life in Calcutta. So much so that these paintings came off as journalistic in their nature of reportage, of which the Elokeshi scandal series is the biggest witness.

By dismissing these works of art as mere representation of the obscenities of the Elite through the eyes of the patua would mean dismissing the various layers that lead to the creation of visual art. To forget the location of representation, projection of self on the other through the self from the perspective of a location that was left behind is what creates the scandal in the art that Kalighat patachitra as a style was then. To recreate the style now would create something entirely different in meaning. There were various reasons behind the extinction of this art form; in the last chapter I discussed lithographs as one of the major pillars of destruction (Pinney, 2004). In the final segment I will be discussing Jamini Roy as the second and most important pillar and the eventual road to museumization as the third. By exploring the works of Jamini Roy in comparison with Kalighat paintings, the concept of counter representation evolves. It maps the movement of the folk who used to represent the folk, into the city. In the city these folk artists represented the plights of the metropolitan beings through folk motifs and Jamini Roy in turn takes the folk back to the folk by force by representing the folk from his class location.

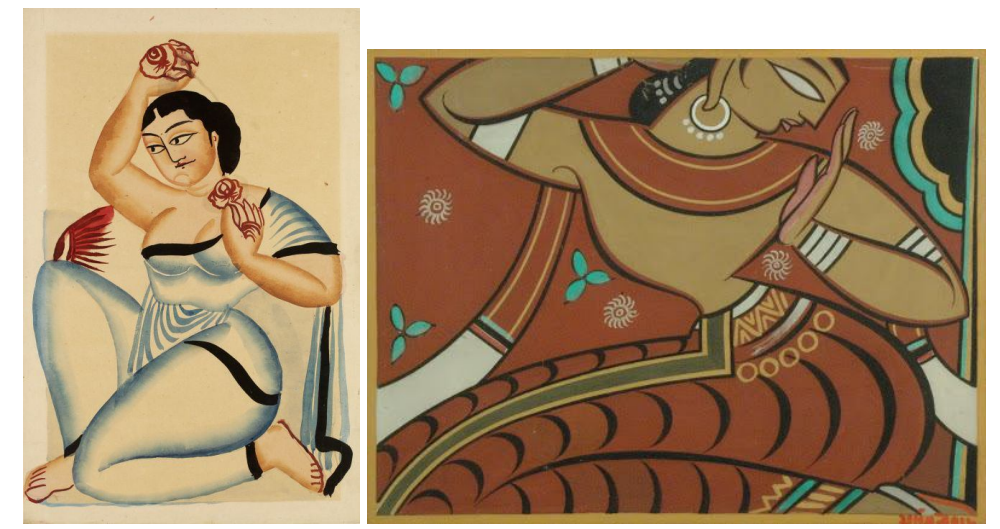

Figure 6 Left. Golapsundari/ Rose beauty. Artist unknown, Kalighat Patachitra. Right. Gopini. Jamini Roy.

\section{The Two Moments of Nationalism}

Jamini Roy on his journey towards creating the now popularized images of the three women and Janani stopped by the explore Kalighat paintings. He acknowledged the debt of learning from this art form and was fairly quick to dismiss it."Roy rejected Kalighat artists for having lost the rural ideal when they moved to Calcutta to serve an urban population. In the mid-192os, he embarked on his epic journey to the Bengal countryside to collect folk paintings (pats) and to learn from the folk painters. He was convinced that the 'revival of Bengali art will not come from Ajanta, Rajput and Mughal art ... [for] one may learn a language that is not one's own but one cannot enter its inner thoughts'."(Banerjee, 1987)

With his class location in the society he was able to problematize the need to serve a population that had a perspective very different from that of the rural and the pristine exotic. Jamini Roy's effort was to make the local, national. In going back to one's roots he believed he could undo the hegemony of the metropolitan on art, in the process he out did the same strata that he was trying to work for, that of the artisans. Jamini Roy delved much deeper into purity and impurity of an 
ideal nationalist through his works. Therefore, the artisan that had migrated, who was trying to portray his immediate surroundings was impure and the artisan ( himself) who had the ability to go back to the roots could purify his class of the hegemony of the ruler by projecting such works nationally and abroad. His onus of nationalism was exactly this, the protection of the idyllic, 'image' of the rural that outdid the image of the metropolitan.
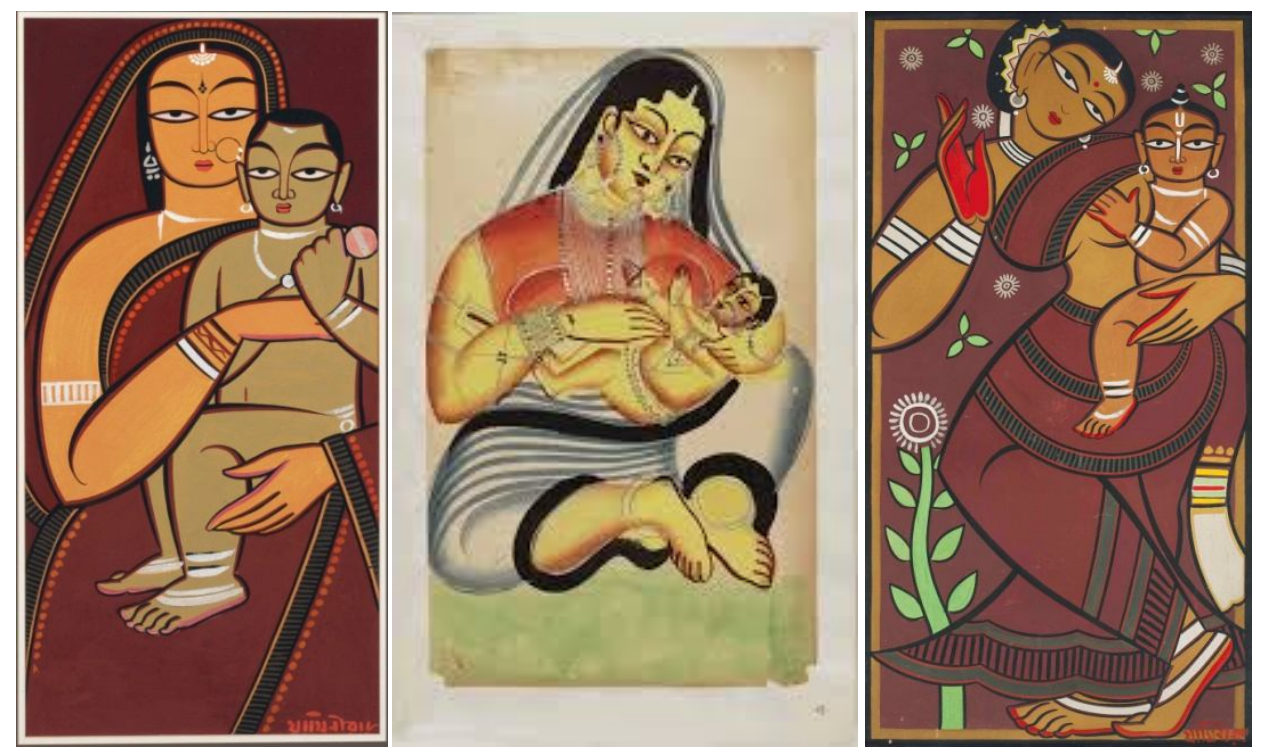

Figure 7 left and right. Janani. Jamini Roy. Centre. Mother and child. Kalighat patachitra, artist unknown.

The complexity of this discourse is such that the bhadralok community continued to draw boundaries and widen the gap of knowledge systems by holding on to paintings by Jamini Roy as the souvenirs of their native selves and as a prominent marker of cultural capital, even to this day. The similarities and measured differences of the works of Jamini Roy and the patuas are such that the covert visual violence remains evident upon comparison.

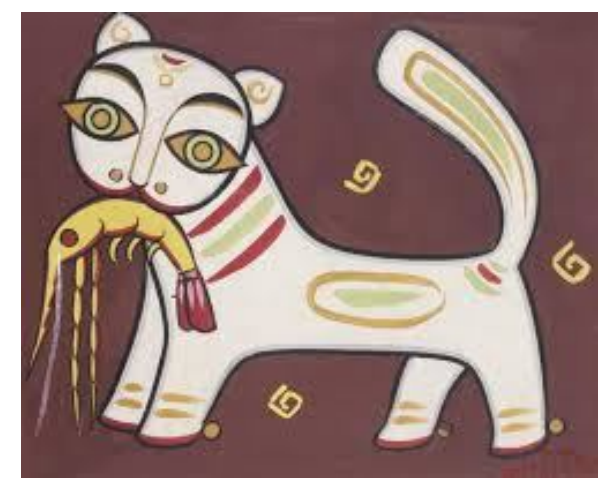

Figure 9 Cat with a fish in its mouth. Jamini Roy.

The earth tones used as a background legitimize his presence in the rural and his representation of it that differentiated the Kalighat Paintings from his works. Kalighat paintings were spatially fluid in nature by the use of lighter colors that signified the private domain of leisure, whereas Jamini Roy predominantly portrayed an environment of rural work culture. In these differences of background what comes up is the presence of a background itself. By using the same frames/ themes for the paintings he displaces the Kalighat pats from the metropolitan into the rural, using motifs like that of a hut, trees, leaves and alpona.

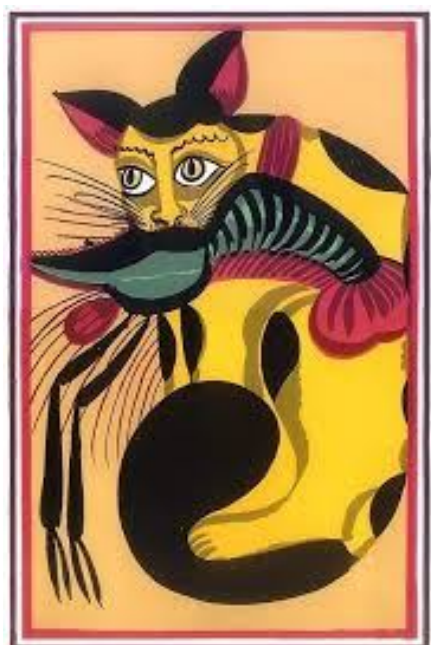

Figure 8 Cat with a fish in its mouth. Kalighat patachitra, Artist unknown.

"Jamini Roy's neo-folk painting had no valid lore to back itself with; its intentions were apparently confined to aesthetic parallelism. So it never rose to any degree of authenticity; it never had the 
earthiness and verve (or the sly humor) of its close folk prototypes, whether those of Kalighat or Puri" (Sen, 1991)

In the process of contemporizing the past and domesticating the body of the woman he had frozen the indigenous roots of the Elite into a frame that would help his nationalist agenda, he also halted the fluidity in the nature of the Kalighat Paintings that evidently wasn't stuck in time in active practice, it portrayed the contemporary in the contemporary.

Bishnu Dey recalls that Jamini Roy's inability to comprehend the contemporary problems which the Patuas had grasped severed him from the ongoing tradition which had acted as his basic inspiration. His paintings therefore became static. It is here that he differs from the visual schema of Kalighat Pata, which retains dramatic movements and violent gestures, so necessary to the satirical tone of its theme. Jamini Roy completely omits these actions. In the process he misses the humor and the power of the female forms which are created as special stereotypes in Kalighat Pata. "There is not a single shrewish woman, not a single violent action in Jamini Roy's paintings" (Chatterjee, Dey, 1987)

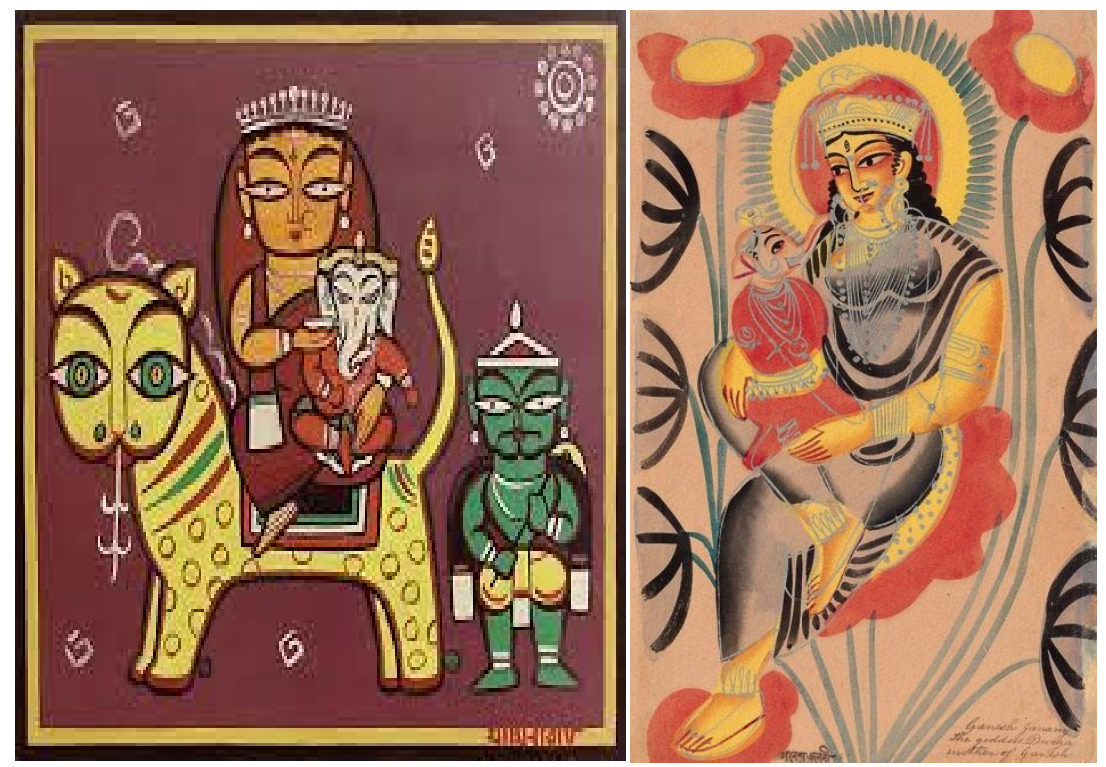

Figure 10 Left. Ganesh Janani. Jamini Roy. Right.Kamala Kamini nursing Ganesha. Artist unknown, Kalighat patachitra.

The most lucrative motif created by Jamini Roy was that of the Eye which was a borrowed treasure. The difference in portrayal of the eyes I believe marked a major divide in their popularity. The eyes of the beings in Jamini Roy's paintings connect with the viewer, whereas the eyes of the women, men and animals is Kalighat Patachitra are self-engaged. What I am trying to say is that the women, the cat, durga, ganesh and even asura stares back at the viewer with a dead pan expression, while the observed in the Kalighat paintings simply disengage themselves from the viewer. This throws immense light into the nature of the subaltern as seen by the Elite in the nineteenth century. The disengagement of the portrayed is a choice made by the artist, as all of them are essentially elite, even the prostitute. Hence, they are observed by the patua as selfengaged, as people who wouldn't look back at the subaltern. They were seen as people who were submerged so deep in the foundation of a new identity that they wouldn't be able to connect with the subaltern artist. 
While through Jamini Roy we learn the need to connect with the subaltern by engaging with them directly through visual contact. It is the discretion of the elite to use the subaltern as a tool of nationalism, as a token of the foundation the Elite's being and as an object to eroticize, to demand engagement with one's audience.

Art isn't created in vacuum, it is derived and Jamini Roy overlooked the derivation of his own dominant style in his mission to preserve and therefore desexualize the body of folk by transforming it into spiritual. We can go back to Sumanta Banerjee's concept of obscenity and the folk culture here and realize that by desexualizing the folk, Jamini Roy was predominantly changing the image of what he was borrowing from. His indebtedness therefore existed for his imagination of folk art and not folk art in itself.

Ratnabali Chatterjee in her understanding posits that "when the modern Bengali artist suddenly found himself catapulted into the world market as a producer, he had only two options open to him: either to acknowledge the entire Western tradition of 'great art' as his own, or to identify with nationalist art" (Chatterjee, 1987) Similar to Jamini Roy were his contemporaries, Abanindranath Tagore, MukulDey and Nandalal Bose. All of the mentioned artists dabbled in Kalighat pat, though not as much as Roy, they belonged to the elite nationalist coup of art that was largely commissioned by active nationalists of that time. Especially, Mahatma Gandhi. "Nandalal's posters (wall panels) for the Haripura Congress, produced at Gandhi's behest, gave him the greatest personal satisfaction and brought him nationwide attention. This time Gandhi set him the task of organizing the exhibition displays in such a way that the local villagers could gaze at them as they went about their daily business. Gandhi's encouragement to artists to reach the ordinary villagers became a Congress ideal from now on." (Mitter, 2007)

Thus, Kalighat paintings were such that the pioneers of contemporary art in Bengal borrowed its form openly and changed its content so much that it became unrecognizable to the point of it losing its importance in its place of origin. Eventually the patua stopped creating for various reasons known and unknown. He was not only heavily criticized but also a victim of industrialization. During this time of crisis and before many of these paintings were taken back by the retreating colonizers. A large collection of these paintings reside in the Victoria and Albert Museum, London and Cleaveland Museum of Art. In Calcutta itself the collections are spread out among the Ashutosh museum in Calcutta University, Gurusaday museum and Victoria Memorial. All of the three collections remain disorganized to this day.

Unsurprisingly, these paintings were museumised within less than hundred years of its creation. Due to its folk origin it was easier to museumise a series of paintings that were painted without a mark of identification. Without a claim of ownership, these paintings that were residing abroad in archives for at least 20 years were museumised without any claims from its country of origin, unlike that of the works of Jamini Roy that are protected in this country by law. Kalighat patachitra is rarely practiced in the city anymore. The rounded susceptibility of folk art that was made in the city, about the city became static when it was turned into an artifact that reminded of a practiced fluid art in nineteenth century, Calcutta.

It is almost as if the ability of the subaltern to speak for themselves is defined in the fact that folk can only be contemporized by the willingness of the Elite to contemporize it and not in folk wanting to contemporize itself in the metropolitan. The expression of such a voice is locked up in frames on museum walls. 


\section{References}

Archer, W.G. (1971).Kalighat Paintings, Victoria and Albert Museum. Butler and Tanner, London.

Banerjee, Sumanta. (1987). Bogey of the Bawdy: Changing Concept of 'Obscenity' in 19th Century Bengali Culture.Economic and Political Weekly, Vol. 22, No. 29. pp. 1197-1206

Banerjee, Sumanta. (1993). The 'Beshya' and the 'Babu': Prostitute and Her Clientele in 19th Century Bengal. Economic and Political Weekly, Vol. 28, No. 45). pp. 2461-2472.

Bannerji, Himani. The Canadian Journal of Sociology / Cahiers canadiens de sociologie, Vol. 19, No. 2 ?

Bannerji, Himani. (1989). Economic and Political Weekly, Vol. 24, No. 19 pp. 1041-1051.

Bagchi, Jashodhara. (1993). Economic and Political Weekly, Vol. 28, No. 41 .pp. 2214-2219.

Basu, Rituparna. (2010). Proceedings of the Indian History Congress, Vol. 70 .pp. 512-520.

Bhowmick, Atul Chandra. (1995). Indian Anthropologist, Vol. 25, No. 1 .pp. 39-46, Indian Anthropological Association

Chatterjee, Partha. (2000). The Nation and Its Women, A Subaltern Studies Reader 1986-95, Oxford University Press,2000). Pp.240-262.

Chatterjee, Ratnabali. (1987). 'The Original Jamini Roy': A Study in the Consumerism of Art, Social Scientist, Vol. 15, No. 1 .pp. 3-18.

Chaterjee, Ratnabali. (2000). Representation of Gender in Folk Paintings of Bengal, Social Scientist, Vol. 28, No. 3/4 ·pp. 7-21.

Chatterjee, Ratnabali. (1993). Prostitution in Nineteenth Century Bengal: Construction of Class and Gender,Social Scientist, Vol. 21, No. 9/11.pp. 159-172.

Chopra, Suneet. (1990). The Folk in Modern Art, India International Centre Quarterly, Vol. 17, No. 2 .

Dahmen Dallapiccola, L. (1975). Kalighat Paintings in the J. u. E. von Portheim-Stiftung, Heidelberg, AAUC/UAAC (Association des universités d'art du Canada / Universities Art Association of Canada), RACAR: revue d'art canadienne / Canadian Art Review, Vol. 2, No. 2 .pp. 25-36.

Das, Aurogeeta. (2010). Metropolitan and Traditional: An Exploration of the Semantics in Contemporary Indian Arts Discourse, Etnofoor, Vol. 22, No. 1, Imitation .pp. 118-135.

Ghosh, Pika. (2003). Unrolling a Narrative Scroll: Artistic Practice and Identity in Late-Nineteenth Century Bengal, Association for Asian Studies, The Journal of Asian Studies, Vol. 62, No. 3 .pp. 835-871.

Ghosh, Srabani. (1986). "Birds in a Cage": Changes in Bengali Social Life as Recorded in Autobiographies by Women, Economic and Political Weekly, Vol. 21, No. 43 .pp. WS88-WS96.

Guha Thakurata, Tapati. (2011). The City in the Archive, Calcutta's Visual Histories,Seagull Arts and Media Resource Centre, Calcutta.

Guha Thakurata, Tapati. (1991). Women as 'Calendar Art' Icons: Emergence of Pictorial Stereotype in Colonial India, Economic and Political Weekly, Vol. 26, No. 43.

Mitter, Partha.(1993).The Making of a New 'Indian Art': Art, Aesthetics and Nationalism by Tapati GuhaThakurta.

Mitter, Partha. (2007). The Triumph of Modernism, India's artists and the avant-garde 1922-1947. Reakton Books London.

Said, Edward. (1978). Orientalism, Pantheon Books.

Sarkar, Tanika. (1987). Nationalist Iconography: Image of Women in 19th Century Bengali Literature, Economic and Political Weekly, Vol. 22, No. 47.), pp. 2011-2015. 
Sen, Arupkumar. (1991). A Discourse on Nineteenth Century Bengal, Economic and Political Weekly, Vol. 26, No. 1/2 .pp. 66-68.

Singh, Lata. (2007). Economic and Political Weekly, Vol. 42, No. 19 .pp. 1677-168o.

Sirhandi, Marcella C. (1999). Art Journal, Vol. 58, No. 3. pp. 40-47

Urban, Hugh B. (2001). The Journal of Asian Studies, Vol. 6o, No. 4. pp. 1085-1114.

Figure 1 Retrieved from https://www.brooklynmuseum.org/opencollection/objects/159650. Accession number 2000.98.4

Figure 2 Retrieved from https://hinducosmos.tumblr.com/post/138899449435/tiger-woman-kalighatpainting-artist-kalam

Figure 3 Retrieved from https://www.lot-art.com/auction-lots/Indian-Kalighat-Painting/103aindian_kalighat-07.4-altair

Figure 4 Retrieved from https://te.wikipedia.org/wiki/\%Еo\%Bo\%A6\%Еo\%Bo\%B8\%Еo\%B1\%8D\%Еo\%Bo\%A4\%Еo\%B1\%8D\%Еo\% Bo\%Bo\%Eo\%Bo\%82:Kalighat_Painting_Calcutta_19th_Century__Woman_Striking_Man_With_Broom.jpg

Figure 5 Retrieved from https://en.wikipedia.org/wiki/Tarakeswar_affair

Figure 6 (left) Retrieved from https://www.gounesco.com/gcp-unfolding-painted-world-revisiting-kalighatpaintings/.

(right) Retrieved from https://artsandculture.google.com/asset/gopini/NwGbst29s5_6BQ

Figure 7 (left and right) retrieved from https://timesofindia.indiatimes.com/blogs/plumage/jamini-roy-130years-of-love-for-santhals/

(Centre) Retrieved from https://in.pinterest.com/pin/474144667014259664/?lp=true

Figure 8 Retrieved from https://in.pinterest.com/mamasuranyabooks/show-your-kids-the-magnificentworks-of-jamini-roy/

Figure 9 Retrieved from https://www.vam.ac.uk/shop/cat-with-a-fish-in-its-mouth-2006ap2493.html

Figure 10 (left) Retrieved from https://www.mutualart.com/Artwork/Untitled--Ganesh-and-Janani/2DFBEC8BCA860661

(right) Retrieved from https://www.artgallery.nsw.gov.au/collection/works/EP3.1959/ . Accession number $\mathrm{EP}_{3.1959}$

http://indiatoday.intoday.in/story/kalighat-patuas-the-folk-artists-who-documented-the-entiregamut-ofbengali-life/1/263880.html

https://www.timeshighereducation.com/books/talking-patua-in-calcutta/158026.article

http://www.openthemagazine.com/article/arts/oh-calcutta

http://www.daricha.org/ExpertSpeakDetails.aspx

https://en.wikipedia.org/wiki/John_Lockwood_Kipling

http://www.chitralekha.org/category/subject/kalighat-painting 